\title{
Addressing the Affordability Crisis for International Students
}

\author{
Rahul Choudaha \\ DrEducation, USA
}

\begin{abstract}
Affordability to study overseas has always been one of the biggest challenges for most aspiring international students. However, in a postrecession environment, this challenge has become more intense for a range of reasons, including budget cuts, demographic changes, economic shifts, and immigration policies. Many universities, especially in high-income countries, are at risk of pricing themselves out of reach to a large segment of international students.
\end{abstract}

\section{THE DEEPENING AFFORDABILITY CRISIS}

Consider the case of the United States, where an increase in direct cost due to a combination of two factors - tuition fees escalation and currency devaluation - is a big blow to affordability. In 2018-2019, the average out-of-state tuition and fees and room and board at a public 4-year institution was $\$ 37,430$ as compared to $\$ 32,762$ in 2014-2015 - an increase of 14\% (College Board, 2018). At the same time, currencies in some of the key emerging countries have devalued against the U.S. dollar. For example, between August 2014 and August 2018, the Indian currency has depreciated by over $20 \%$. The net effect is that for an Indian undergraduate student, the cost of attendance in 2018-2019 increased by at least 30\% as compared to 2014-2015.

In addition to increasing direct cost, lower availability of funding opportunities from universities and governments, as well as tighter immigration and visa policies for finding work opportunities, is making it harder to recover the cost of education. The trend of higher tuition fees for international students is not just in the United States and other leading English-speaking destinations. Even countries in continental Europe have started introducing tuition fees for international students. For example, Denmark (in 2006) and Sweden (in 2011) introduced tuition fees for international students from outside the European economic area (Marconi \& Serra, 2017). 


\section{THE INCREASING DEMAND FOR "VALUE FOR MONEY"}

The future competitiveness of higher education institutions and nations in attracting international students hinges on their ability to demonstrate "value for money," could be defined as the "reasonableness of cost of something in view of its perceived quality". In other words, the increase in the cost side of the equation demands that institutions and policymakers must do more to balance by offering more benefits in terms of better experiences on- and off-campus, especially in terms of career outcomes. Institutions must do more to reinvest part of the additional tuition fees back into enhancing outreach, offering scholarships, supporting student success, and widening access to students who may be unable to afford to study abroad.

For many students who get priced out of reach to study in high-income countries, emerging destinations such as China offer new hope to gain global experience at an affordable price. A prime example of this scenario is the rise of students from lowincome countries. For instance, in 2018, one out of six international students in China was from Africa (Ministry of Education, 2018). This potential of China as a destination for international students is not only because of affordability factors in leading destinations, but also because of proactive national policies in China such as the Belt and Road Initiative, and Double-First Class, which are mutually reinforcing each other.

\section{SHAPING THE RESEARCH AGENDA}

We are heading toward a future scenario where global learning experiences will be out of the reach of many aspiring international students. This is a wake-up call to action for researchers, policymakers, practitioners, and leaders to focus on finding solutions to this affordability crisis, which threatens the future of international student mobility.

The Journal of International Students plays an indispensable role in not only shaping the research agenda to raise awareness about the affordability crisis but also in providing evidence for potential solutions. On this important milestone of the 10th anniversary for the Journal, I encourage scholars to consider the role of affordability challenges and its various implications and dimensions. In conclusion, we have an opportunity and a responsibility to reflect and plan a future research agenda that ensures the sustainability of international student mobility and enhances the diversity and inclusion of international students.

\section{REFERENCES}

College Board. (2018). Trends in college pricing. https://research.collegeboard.org/trends/college-pricing

Marconi, G. \& Serra, D. S. (2017). Tuition fee reforms and international mobility. Education Indicators in Focus, 51. OECD Publishing. https://doi.org/10.1787/2dbe470a-en

Ministry of Education (2018). Statistical report on international students in China. http://en.moe.gov.cn/documents/reports/201904/t20190418_378692.html 
RAHUL CHOUDAHA, $\mathrm{PhD}$, is a global higher education strategist and principal researcher at DrEducation. As a U.S.-based scholar-practitioner, he advises, presents and publishes on mobility, experiences and enrollment of international students. $\mathrm{He}$ has chaired or presented nearly 150 sessions at professional conferences and has been quoted over 300 times in global media. He is a member of the Editorial Advisory Board of the Journal of International Students and editor of the Special Issue on International Student Success. Email: rahul@dreducation.com 